\title{
Pelaksanaan Program Gerakan Maghrib Mengaji di Masjid Al- Furqan Kelurahan Cipaganti Kota Bandung
}

\section{Hapsoh* $^{*}$}

Prodi Pendidikan Agama Islam, Fakultas Tarbiyah dan Keguruan, Universitas Islam Bandung, Indonesia.

*hapsoh42@gmail.com

\begin{abstract}
The implementation of the maghrib recital movement program is an activity that provides non-formal education and teaching in the field of Islam. The maghrib recital movement is a program issued by the government aimed at all levels of society, but focuses on children and adolescents so that teenagers fill their maghrib time with activities at the mosque instead of hanging out. The purpose of this study is to find out what activities are prepared, to identify how the steps of the activities are, to find out what methods and media are used, and to find out who is involved in the implementation of the maghrib reciting movement program at the Al-Furqan mosque. This study uses a qualitative approach and analytical descriptive method. Data collection techniques used in the form of interview teachniques, observation teachiques, and documentation teachniques. Data analysis begins with data reduction at the beginning, data presentation and conclusion drawing. The results of this study include: (a) activities that are prepared in carrying out the maghrib reciting movement program. First, prepare teachers in terms of reading/recitation of the recital propely in accordance with the rules. Second, supporting devices or tools such as the recital, stationery and others. Third, the mentality of the teachers and students to continue to be enthusiastic to recite the recital and run the maghrib recital movement program. (b) the activity steps in implementing the maghrib recital movement program are through three stages, preliminary activities, core activities and closing activities. (c) the method used in the implementation of the maghrib recital movement program is to use the classical method in learning and the lecture, question and answer and deposit (Tes) method. In the learning process, teachers often improvise one method with another method. (d) the media used in the implementation of the maghrib recital movement program include blackboards, stationery, microphones, sound systems and infocus. (e) the parties involved in the implementation of the maghrib reciting movement program are the community around the mosque, at DKM and teacher parents of students.
\end{abstract}

Keywords: Program, Maghrib study, Students

Abstrak. Pelaksanaan program gerakan maghrib mengaji merupakan kegiatan yang memberikan pendidikan dan pengajaran di bidang agama Islam secara nonformal. Salah satu program yang dikeluarkan oleh pemerintah untuk pembiasaan masyarakat khususnya untuk kalangan anak-anak dan remaja, yaitu program Gerakan maghrib mengaji. Program ini salah satu upaya pemerintah untuk membiasaan masyarakat agar mengisi waktu maghrib nya dengan mempelajari Al-Qur'an. Pelaksanaan program gerakan maghrib mengaji ini menerangkan mengenai, kegiatan yang dipersiapkan dalam melaksanakan program maghrib mengaji, langkah-langkah, metode, media dan pihak-pihak yang terlibat dalam pelaksanaan program gerakan maghrib mengaji. Tujuan dari penelitian ini adalah untuk menemukan apa saja kegiatan yang dipersiakan, untuk mengidentifikasi bagaimana langkah-langkah kegiatan, ntuk menemukan metode dan media apa saja yang digunakan, dan untuk mengetahui siapa saja yang terlibat dalam pelaksanaan program gerakan maghrib mengaji di masjid Al-Furqan. Deskriptif analitik merupakan metode yang digunakan oleh peneliti dengan melalui pendekatan kualitatif, sedangkan wawancara, observasi serta dokumentasi ialah teknik pengumpulan data yang dilakukan oleh peneliti untuk mendapatkan data penelitian. Analisis data diawali dengan reduksi data diawal, penyajian data dan penarikan kesimpulan. Hasil dari penelitian ini meliputi: (a) kegiatan yang dipersiapkan dalam melaksanakan program gerakan maghrib mengaji Pertama, mempersiapkan pengajar dari segi bacaan/lafadz al-Quran dengan baik sesuai dengan kaidah, Kedua, perangkat atau alat pendukung seperti al-Quran, alat tulis dan lain-lainnya. Ketiga, mental para pengajar dan santri agar terus semangat untuk mengaji dan menjalankan program gerakan maghrib mengaji ini. (b) Langkah-langkah kegiatan dalam melaksanakan program gerakan maghrib mengaji yaitu melalui tiga tahap, kegiatan pendahuluan, kegiatan inti dan kegiatan penutup. (c) Metode yang digunakan dalam pelaksanaan program gerakan maghrib mengaji ialah menggunakan metode klasik dalam pembelajarannya dan metode cerama, tanya jawab dan setoran (TES), Pada proses belajar pengajar sering kali mengimprovisasi metode yang satu dengan metode yang lain. (d) Media yang digunakan dalam pelaksanaan program gerakan maghrib mengaji diantaranya, papan tulis, alat tulis, mic, soud system, serta infocus. (e) Pihak-pihak yang terlibat dalam pelaksanaan program gerakan maghrib mengaji adalah masyarakat sekitaran masjid, di DKM dan pengajar, orangtua santri.

Kata Kunci: Program, Maghrib Mengaji, Santri. 


\section{A. Pendahuluan}

Menurut Ramayulis melalui kegiatan pembiasaan kegiatan pengajaran, bimbingan serta latihan, Pendidikan agama islam merupakan upaya terencana serta sadar dalam mengimani, menghayati, mengamalkan ajaran agama Islam dari sumber kitab Al-Qur'an serta Hadits. (Ramayulis, 2005) hadist Rasulullah SAW yang menjelaskan sunah berdoa ketika waktu maghrib tiba. Rasulullah SAW, bersabda:

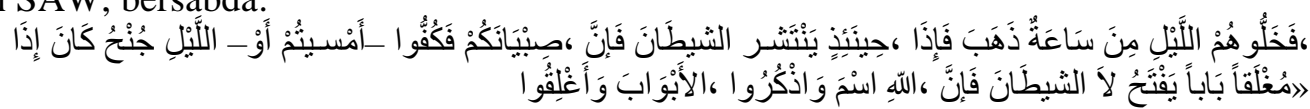

(HR. Al-Bukhari no. 3304 dan Muslim no. 2012).

Makna hadits diatas ialah, Nabi memerintahkan umatnya untuk menahan anak-anak berkeluyuran diluar rumah, mengunci rapat-rapat pintu rumah, serta menutup makanan yang terbuka pada waktu menjelang maghrib dating, karena pada saat ini semua pintu-pintu setan terbuka. Maka dari itu dianjurkan untuk memperbanyak doa pada waktu menjelang maghrib.

Adapun amalan-amalan yang dianjurkan untuk dilakukan pada saat menjelang maghrib yaitu mengerjakan amal shaleh. Ada 4 amal shaleh yang dianjurkan dilakukan, diantaranya: Shalat, Dzikir, Baca Al-Qur'an, dan Irikaf.

Selaras dengan salah satu Hadits tentang seseorang yang mempelajari Al-Qur'an adalah sebaik-baiknya umat:

\section{[Al-Bukhari]}

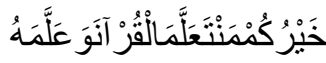

$$
\begin{aligned}
& \text { رواهالبخاري }
\end{aligned}
$$

Maknanya ada dua sifat yang terbaik yaitu: orang yang senantiasa mempelajari AlQur'an dan mengajarkannya. Ia mempelajari Al-Qur`an dari gurunya, kemudian ia mengajarkan Al-Qur`an tersebut kepada orang lain. Mempelajari dan mengajarkannya di sini mencakup mempelajari dan mengajarkan lafazh-lafazh Al-Qur`an, mempelajari dan mengajarkan maknamakna yang terkandung dalam Al-Qur`an. Untuk membangun perkembangan masyarakat khususnya pada kalangan anak-anak dan remaja menjadi lebih baik, perlunya suatu pendidikan yang membangun, dan pendidikan agamalah yang paling tepat. Terutama saat perkembangan zaman yang semakin pesat semakin banyak pula permasalahan agama yang muncul di masyarakat. Peran pendidikan nonformal, khususnya pendidikan agama sangat membantu untuk meminimalisir permasalah yang terjadi di masyarakat. Pendidikan nonformal adalah bentuk kegiatan pendidikan yang terorganisasi atau yang berlangsung diluar sistem persekolahan yang ditujukan untuk melayani kebutuhan belajar dari berbagai kelompok penduduk, baik tua maupun muda. Melalui keputisan mentri agama Repuplik Indonesia nomor 150 tahun 2013, kementrian agama mengeluarkan program Gerakan Masyarakat Maghrib Mengaji (GEMMAR Mengaji / GM3) segbagai upaya yang dilakukan oleh pemerintah untuk memberikan pendidikan agama secara non formal. Mesjid ini dijadikan sebagai lokasi penelitian karena mesjid ini memiliki banyak santri di banding RT lain, dan dalam pelaksanaan serta pengajaran dilakukan oleh pemuda-pemudi di daerah tersebut menggunakan metode - metode yang cukup menarik, santri-santri dan pengajar nya yang memiliki akhlak dan perilaku yang baik dan sopan, sehingga orangtua mempercayai anak-anaknya untuk mengaji di masjid tersebut. Selain itu remaja di kelurahan Cipaganti ini khususnya RW 01 remaja nya lebih aktif dalam memakmurkan masjid dan pada saat maghrib mereka lebih memilih untuk mengaji di mesjid dari pada berkeluyuran atau berdiam di rumah menonton tv atau main game dan lain - lain. Oleh karena itu peneliti akan meneliti mengenai bagaimana pelaksanaan maghrib mengaji di masjid Al-Furqan. Berdasarkan latar belakang yang telah dijelaskan diatas maka peneliti tertarik mengabil judul penelitian "Pelaksanaan Program Gerakan Maghrib Mengaji Santri di Masjid Al-Furqan Kelurahan Cipaganti Kota Bandung.

\section{Tujuan Penelitian}

1. Untuk menemukan kegiatan apa saja yang dipersiakan dalam melaksanakan program gerakan maghrib mengaji di masjid Al-Furqan kelurahan Cipaganti Kota Bandung.

2. Untuk mengidentifikasi bagaimana langkah-langkah kegiatan dalam melaksanakan program gerakan maghrib mengaji di masjid Al-Furqan kelurahan Cipaganti Kota 
Bandung.

3. Untuk menemukan metode apa saja yang digunakan dalam pelaksanaan program gerakan maghrib mengaji di masjid Al-Furqan kelurahan Cipaganti Kota Bandung.

4. Untuk mengetahui apa saja media yang digunakan dalam pelaksanaan program gerakan maghrib mengaji di masjid Al-Furqan kelurahan Cipaganti Kota Bandung.

5. Untuk mengetahui siapa saja yang terlibat dalam pelaksanaan program gerakan maghrib mengaji di masjid Al-Furqan kelurahan Cipaganti Kota Bandung.

\section{B. Metodologi Penelitian}

Peneliti menggunakan pendekatan kualitatif dengan metode deskriptif anaitik menurut moleong (2011) bahwa penelitian kualitatif merupakan penelitian yang bermaksud untuk memahami fenomena tentang apa yang dialami oleh subyek penelitian misalnya perilaku, persepsi, motivasi, tindakan secara holistic dengan cara mendeskripsikannya ke dalam kata bentuk kata dan bahasa. Peneliti menggunakan metode dan pendekatan ini untuk meneliti secara langsung situasi di lapangan terkait pelaksanaan program gerakan maghrib mengaji di masjid Al-Furqan keluran Cipaganti. Sesuai dengan tujuan dari peneliti yaitu ingin mendeskripsikan, menemukan, mengetahui, mengungkapkan, bagaimana pelaksanaan program gerakan maghrib mengaji di masjid Al-Furqan meiputi kegiatan yang dipersiakan, langkah-langkah kegiatan, metode, media dan Siapa saja yang terlibat dalam pelaksanaan program gerakan maghrib mengaji di masjid AlFurqan.

Jenis data yang digunakan oleh peneliti menggunakan jenis data Kualitatif. Peneliti mengambil data kualitatif dengan menggunakan wawancara kepada pengurus DKM dan pengajar dengan observasi dan dokumentasi di lapangan sehingga mendapatkan data secara kualitatif.

Peneliti menggunakan dua pengambilan sumber data yang pertama, sumber data primer ini adalah data yang diambil berdasarkan wawancara. Adapun sumber data primer dalam penelitian ini adalah pihak - pihak yang terlibat di dalam program gerakan Maghrib mengaji yaitu ketua DKM Al-Furqan, pengajar data yang diambil langsung dari sumbernya yang menjadikan data relevan dengan kondisi yang terjadi di lapangan. Yang kedua, Peneliti mengambil data sekunder adapun sumber data seperti dokumen-dokumen yang berhubungan dengan kegiatan pelaksanaan program gerakan maghrib mengaji.

Teknik observasi, wawancara serta dokumentasi adalah teknik pengumpulan data yang dilakukan oleh peneliti. Adapun analisi data yaitu data yang diperoleh di reduksi, lalu disajikan melalui deskriptif dan disimpulkan oleh peneliti.

\section{Metode Pembelajaran}

Pendapat Abdul Azis kegiatan pendidikan yang terarah yang menyebabkan siswanya belajar, untuk menunjukkan serangkaian pembelajaran disebut dengan metode (Wahab, 2007)

Adapun menurut (Sutikno, 2009) cara-cara dalam menyajikan materi pembelajaran yang ditransferkan kepada murid agar terjadinya proses pembelajaran pada diri siswa dalam upaya mencapai tujuan disebut metode pembelajran. Sedangkang metode pembelajaran menurut (Djamarah, 2006) 'suatu cara yang dipergunakan untuk mencapai tujuan yang telah ditetapkan'. Dalam kegiatan belajar mengajar, metode diperlukan oleh guru agar penggunaanya bervariasi sesuai yang ingin dicapai setelah pengajaran berakhir.

Dari beberapa pendapat para ahli dapat disimpulkan bahwa metode pembelajaran merupakan cara yang digunakan guru untuk menyampaikan bahan pelajaran kepada peserta didik agar terjadi proses belajar demi tercapainya tujuan pembelajaran. Pendapat ini secara umum memiliki kemiripan dengan sebelumnya di mana metode menekankan pada proses upaya mempermudah penguasaan cara guru untuk menyampaikan materi pembelajaran. Kegiatan belajar mengajar akan semakin efektif dan efisien apabila menggunakan metode pembelajaran yang tepat dalam kegiatan belajar mengajar. Sehingga akan menghasilkan keberhasilan suatu pembelajaran. Metode yang digunakan harus memiliki kedudukan sebagai alat untuk mencapai tujuan pembelajaran. Maka metode apa pun yang digunakan dalam sebuah pembelajaran haruslah di dalamnya mengandung tugas penting mencapai tujuan pembelajaran. 


\section{Media Pembelajaran}

Media dapat disebut juga sebagai pengantar atau penghubung, yang mengantarkan atau menghubungkan atau menyalurkan sesuatu hal dari satu sisi ke sisi yang lain. Yang dimaksud sebagai media dalam pembelajaran adalah guru, buku teks, dan lingkungan. Lebih khusus media dalam pembelajaran lebih cenderung diartikan sebagai alat-alat grafis, photografis dan elektronik untuk menangkap, memproses, dan menyusun kembali informasi visual atau verbal. (Munadi, 2013) mendefinisikan untuk terciptanya suatu lingkungan belajar yang kondusif, efisien dan efektif memerlukan penyampaian serta penyaluran pesan dari sumber belajar secara terencana.

Sesuai pendapat-pendapat tersebut dapat disimpulkan bahwa media pembelajaran merupakan alat yang digunakan untuk menyalurkan pesan dari sumber belajar yaitu buku atau modul dan sumber belajar lainnya kepada penerima yaitu siswa, agar tercipta lingkungan berlajar yang kondusif, efisien, dan menyenangkan

\section{Hasil Penelitian dan Pembahasan}

Berikut adalah penelitian mengenai pelaksanaan Gerakan maghrib mengaji di masjid Al-Furqan. Pelaksanaan merupakan bentuk realisasi dari rumusan yang ditetapkan oleh Dewan Kemakmuran Masjid (DKM) Al-Ikhlas. Dalam pelaksanaan ini DKM sangat memperhatikan sumber daya manusia. Mereka selalu diberi pengarahan agar program kegiatan dapat dilaksakan dengan baik yaitu dengan menciptakan lingkungan yang sehat, dinamis, solid, dan lain sebagainya. Dengan begitu diharapkan dapat menjalankan kegiatan program-program maghrib mengaji dengan ikhlas dan mengusahakan agar terealisasikan dengan sebaik mungkin.

Sejalan dengan apa yang dikemukakan oleh M manullang bahwasannya dalam mempersiapkan kegiatan yang akan dilaksanakan harus mencakup 5WIH seperti, Tindakan yang dikerjakan dalam mempersiapkan kegiatan maghrib mengaji ialah mengajak masyarakat sekitaran masjid untuk terlibat dalam pelaksanaan program-program maghrib mengaji ini, untuk mewujudkan masyarakat baldatun toyibah warobbun ghofur, dilaksanakannya di masjid, pelaksanaan kegiatan pada ba'da maghrib sampai selesai, sumber daya yang akan mengisi, mengajar, ditugaskan untuk memantau setiap kegiatan maghrib mengaji, dan cara merealisasikan kegiatan dengan menggunakan media, metode yang menarik. Program Gerakan maghrib mengaji di masjid Al-Furqan dilaksanakan pada waktu ba'da maghrib. Sebelum dan sesudah proses maghrib mengaji para santri harus melakukan piket sesuai dengan jadwalnya, setiap hari ada 3-4 orang yang piket. Proses pembelajaran maghrib mengaji dilakukan dari ba'da maghrib hingga pukul 20:00 WIB. Pelaksanaan program Gerakan maghrib mengaji di masjid Al-Furqan dilaksanakan pada waktu ba'da maghrib. Langkah-langkah dalam melaksanakan program gerakan maghrib mengaji ini dibagi menjadi tiga tahap yaitu, kegiatan pendahuluan, kegiatan inti dan kegiatan penutup.

Program Gerakan maghrib mengaji ini berjalan dengan baik karena menggunakan metode-metode terbaik pula. Metode yang dipilih dan digunakan disesuaikan dengan kebutuhan dan keadaan santri di masjid Al-Furqan keluharan Cipaganti. Metode yang digunakan di program maghrib mengaji di masjid Al-Furqan menggunakan metode klasik dalam pembelajarannya dan metode cerama, tanya jawab dan setoran (TES). Dalam proses pembelajaran yang dilakukan menggunakan metode yang sama pada setiap pembelajaran, namun terkadang guru memberi tambahan atau menginprovisasi metode satu dengan metode yang lainnya, agar suasana pada saat proses belajar menyenangkan. Program Gerakan maghrib mengaji ini berjalan dengan baik karena menggunakan media terbaik pula. Media yang dipilih dan digunakan disesuaikan dengaan fasilitas yang ada di masjid Al-Furqan keluharan Cipaganti. Walaupun media yang digunakan masi menggunakan media klasik tetapi tidak mengurangi semangat dan tercapainya tujuan pembelajaran. Media yang digunakan dalam program maghrib mengaji di masjid Al-Furqan ini diantanya, papan tulis, alat tulis, mic, soud system, serta infocus.

Program Gerakan maghrib mengaji takan berjalan dengan lancar tanpa adanya pihakpihak yang telah berjasa membantu dan membangun program ini agar tetap eksis dan tetap berjalan meski banyak rintangan yang harus di lalui. Karena ini bisa menjadi amal jariah bagi 
pihak-pihak yang terlibat karena sudah memakmurkan dan menciptakan wilayah yang gemar mengaji dan membaca al-Quran.

Adapun pihak-pihak yang terlibat dalam pelaksanaan program maghrib mengaji diantaranya, masyarakat sekitaran masjid, DKM dan pengajar dan orangtua santripun dilibatkan dalam pelaksanaan program maghrib mengaji ini agar tujuan yang telah dirumuskan bersama dapat tercapai dengan maksimal.

\section{Kesimpulan}

Hasil penelitian pada pelaksanaan program maghrib mengaji, peneliiti menyimpulkan menjadi sebagai berikut:

1. Berawal dari kesadaran masyarakat masjid Al-Furqan untuk melaksanakan salah satu program pemerintah yaitu maghrib mengaji. Masyarakat sekitar masjid, DKM, beserta jajarannya mempersiapkan kegiatan maghrib mengaji dengan sangat maksimal, dimulai dari dirumuskan tujuan dibentukinya pelaksanaan program maghrib mengaji yaitu, santri masjid Al-Furqan mampu membaca Al-Qur'an dengan baik dan benar, memahami AlQur'an dengan baik dan benar, santri memiliki pribadi yang baik sholeh dan sholehah sehingga dapat terciptanya keluarga/masyarakat yang baldatun thayyibatun wa rabbun ghafur. Kegiatan yang dipersiapkan dalam melaksanakan program maghrib mengaji di masjid Al-Furqan yaitu, pengajar/guru, materi, media, sumber daya manusia/santri, sarana dan prasarana. Pada umumnya dalam mempersiapkan kegiatan membutuhkan rencana. Persiapan program ini sudah berdasarkan teori para ahli denga apa yang harus diterapkan dalam kegiatan yang harus dipersiapkan dalam melaksanakan program. Kegiatan yang dipersiapkan dalam melaksanakan program ini di dapatkan peneliti dari beberapa cara, yaitu melalui wawancara, dan dokumentasi kepada narasumber terkait program ini. Dari persiapan yang dilakukan dapat diketahui bahwa dalam mempersiapkan suatu program perlu adanya rencana dan persiapan dalam segala aspek yang berkaitan dengan program yang akan dijalankan.

2. Gerakan maghrib mengaji di masjid Al-Furqan sudah berlangsung sejak tahun 2017 Langkah-langkah dalam melaksanakan program maghrib mengaji di Al-Furqan, memiliki tiga tahap yaitu kegiatan pendahuluan, kegiatan inti dan kegiatan penutup. Langkah- Langkah pelaksanaan pembelajaran program ini sudah berdasarkan dari teori langkah-langkah pembelajaran yang dicetuskan oleh para ahli. Namun dalam Langkahlangkah pelaksanaan masi terdapat kekurangan dimana pengajar belum terbiasa dengan durasi belajar santri yang terbatas terkadang kegiatan penutup dilaksanakannya kurang maksimal.

3. Metode yang di gunakan dalam proses pelaksanaan program gerakan maghrib mengaji, yang di temukan oleh peneliti di lapangan ialah metode cerama, diskusi tanya jawab dan setoran (TES). Pengajar menggunakan lebih dari satu metode/kolaborasi beberapa metode, sesuai dengan kebutuhan dan target yang akan dicapai oleh pengajar dan santri.

4. Pelaksanaan program maghrib mengaji di masjid Al-Furqan menggunakan media yang disesuaikan dengaan fasilitasa yang ada di masjid Al-Furqan. Media yang digunakan masi menggunakan media klasik diantaranya, papan tulis, alat tulis, mic, soud system, serta infocus. Walaupun menggunakan media seadanya tetapi tidak mengurangi semangat santri untuk tercapainya tujuan pembelajaran.

5. Pelaksanaan program gerakan maghrib mengaji di masjid Al-Furqan ini sudah berlangsung sejak lama/turun temurun namun hanya sebatas tadarus Al-Qur'an. Sejak tahun 2017 mulai dibentuk struktrut dan melibatkan pihak-pihak untuk terlibat dalam pelaksanaan program gerakan maghrib mengaji di masjid Al-Furqan. Pihak-pihak yang terlibat dalam pelaksanaan program maghrib mengaji di masjid Al-Furqan diantaranya, masyarakat sekitaran masjid yang di percaya oleh masyarakat tersebut untuk menjadi DKM dan pengajar, orangtua santri. Pihak-pihak yang terlibat dalam pelaksanaan program maghrib mengaji di masjid Al-Furqan saling Kerjasama dan menjaga kkompakan agar terciptanya tujuan dan wilayah yang gemar mengaji dan membaca alQuran. 


\section{Acknowledge}

Penulis ucapan terimakasih yang sebesar-sebarnya kepada semua pihak yang telah memberikan bantuan dorongan dan arahan, baik secara moril maupun materil dalam proses penyelesaian skripsi ini. Terutama penulis sampaikan kepada:

1. Ibu Dr. Nan Rahmawati, Dra., selaku dosen pembimbing I

2. Bapak Enoh Nuroni, Drs., M.Ag selaku Dekan Fakultas Tarbiyah dan Keguruan Universitas Islam Bandung. Dan pembimbing II

3. Bapak Dr. Aep Saepudin, Drs., M.Ag selaku Ketua Prodi Pendidikan Agama Islam Fakultas Tarbiyah dan Keguruan Universitas Islam Bandung.

4. Bapak Dr. Helmi Aziz, S.Pd.I.. M.Pd.I selaku dosen wali yang telah memberi bimbingan dan motivasi kepada penulis.

5. Seluruh dosen beserta staft Tata Usaha Fakultas Tarbiyah dan Keguruan Universitas Islam Bandung, yang telah memberikan bimbingan dan menuangkan ilmunya kepada penulis sehingga penulis dapat menyelesaikan studi hingga memperoleh gelar sarjana (S1)

\section{Daftar Pustaka}

[1] Manullang, M. (2000). Manajemen Sumber Daya Manusia. Yogyakarta: Andi.

[2] Munadi, Y. (2013). Media Pembelajaran. Jakarta Selatan: Referensi.

[3] Ramayulis. (2005). Metodologi Pendidikan Agama Islam. Jakarta: Kalam Mulia.

[4] Sutikno, S. (2009). Belajar dan Pembelajaran. Bandung: Prospect.

[5] Wahab, A. A. (2007). Metode dan Model-model Mengajar. Bandung: Alfabeta. 